\title{
Retraction Note to: Inflammation and shoulder pain-a perspective on rotator cuff disease, adhesive capsulitis, and osteoarthritis: conservative treatment
}

\section{Bernardino Saccomanni}

Published online: 22 February 2012

(C) Clinical Rheumatology 2012

This article has been retracted due to plagiarism.

The original work is:

Edwards SL, Bell JE, Blaine TA (2006) Inflammation and Shoulder Pain-A Perspective on Rotator Cuff Disease, Adhesive Capsulitis, and Osteoarthritis. Business Briefing: US Orthopedics Review 2006. http://www.touchbriefings. com/download.cfm?fileID $=7662$

This article has been retracted due to plagiarism. The original work is: Edwards SL, Bell JE, Blaine TA (2006) Inflammation and Shoulder PainŠA Perspective on Rotator Cuff Disease, Adhesive Capsulitis, and Osteoarthritis. Business Briefing: US Orthopedics Review 2006. http:// www.touchbriefings.com/download.cfm?fileID $=7662$

B. Saccomanni $(\bowtie)$

University of Chieti via dei Vestini,

66013 Chieti, Italy

e-mail: bernasacco@yahoo.it

B. Saccomanni

Sondalo Hospital via Zubiani Sondalo,

Sondalo, Italy 